\title{
Can agroecological management increase functional diversity of birds in rice fields?
}

\author{
Rodrigo E. Lorenzón ${ }^{1,2 *}$; Evelina J. León ${ }^{1,2,3}$; Marcelo Juani ${ }^{1,4}$; Adolfo H. Beltzer1;
} Paola M. Peltzer, ${ }^{2,3}$; Rafael C. Lajmanovich ${ }^{2,3}$. \& Andrés M. Attademo ${ }^{2,3}$

1. Instituto Nacional de Limnología (INALI-CONICET-UNL), Ciudad Universitaria (3000), Santa Fe, Argentina; roylorenzon@gmail.com, evelinaleon903@hotmail.com, adolfohec2001@yahoo.com.ar, marceloj_8@hotmail.com

2. Consejo Nacional de Investigaciones Científicas y Técnicas (CONICET), Godoy Cruz 2290 (C1425FQB), Ciudad Autónoma de Buenos Aires, Argentina.

3. Laboratorio de Ecotoxicología. Facultad de Bioquímica y Ciencias Biológicas (ESS-FBCB-CONICET), Ciudad Universitaria (3000), Santa Fe, Argentina; paolapeltzer@hotmail.com, lajmanovich@hotmail.com, mattademo@hotmail.com

4. Facultad de Humanidades y Ciencias (FHUC-UNL), Ciudad Universitaria (3000), Santa Fe, Argentina * Correspondence

Received 09-X-2019. Corrected 07-IV-2020. Accepted 02-VI-2020.

\begin{abstract}
Introduction: Recognition of the variety of ecosystem services that biodiversity performs in agroecosystems is one of the basic principles of agroecology. Because indices of functional diversity may be directly related with ecosystem services, an assessment of functional diversity can be useful for evaluating ecosystem services provided under agroecological management. Objective: We compared functional diversity of birds found in rice fields under conventional and agroecological management in the rice zone of Santa $\mathrm{Fe}$ Province, Argentina. Our objective was to determine whether agroecological management of rice is associated with a higher functional diversity and a different functional composition of birds than conventional management. Methods: We surveyed birds eight times, roughly every 15 days between November 2017 and March 2018, from beginning of sowing to before harvest, in both types of rice fields. Birds were sampled by a combined technique of line transects and point counts at four sites in each type of management. We calculated indices of functional diversity and composition based on morphologic and trophic attributes of birds detected in each type of field. Results: Functional richness, divergence and dispersion were higher under agroecological management. Only differences in functional richness between managements reflected differences in species richness. Communitylevel weighted means of trait values by sample varied between management types. An insectivorous diet, pursuit as a foraging method, and air and shrubs as foraging substrates were traits best represented under agroecological management. Conclusions: Our results suggest that agroecological management of rice crops is related with a higher functional diversity of birds than conventional practices, suggesting that agroecological management may enhance the provision of ecosystem services by birds in rice agroecosystems.
\end{abstract}

Key words: agroecosystem; Argentina; conventional management; ecosystem service; Santa Fe province; functional trait.

Lorenzón, R.E., León, E.J., Juani, M., Beltzer, A.H., Peltzer, P.M., Lajmanovich, R.C., \& Attademo, A.M. (2020). Can agroecological management increase functional diversity of birds in rice fields? Revista de Biología Tropical, 68(3), 873-883.

Recognition of the importance of agricultural areas for biodiversity conservation as well as the benefits of biodiversity on production has contributed to the promotion of environmentally friendly agricultural practices, in which agroecological and organic approaches have played a predominant role (Wezel \& Soldat, 2009). One of the basic principles of these management practices is the recognition of the variety of ecosystem services that biodiversity 
performs in agroecosystems (Altieri, 1999). Consequently, a variety of studies have demonstrated that agroecological and organic farms sustain higher biodiversity than farms under conventional agrochemicals-based management (Sans, 2007; Letourneau \& Bothwell, 2008), based on the premise that taxonomic diversity and ecosystem services are related.

More recently, however, it has been recognized that ecosystem-level processes are affected by the functional characteristics of organisms involved, rather than by taxonomic identity (Hooper et al., 2002). This has led to the development of different indices of functional diversity (Villéger, Mason, \& Mouillot, 2008). However, comparisons of biodiversity among different types of agricultural management have primarily measured taxonomic species richness and diversity (Letourneau \& Bothwell, 2008); fewer studies examined functional diversity (Liere, Jha, \& Philpott, 2017). Because functional diversity indices are more directly related with ecosystem services (Hooper et al., 2005; Liere et al., 2017), and because the relationship between species richness and functional diversity depends on various factors (Mayfield et al., 2010; Cadotte, Carscadden, \& Mirotchnick, 2011), a comparison of functional diversity can be an effective approach to assess ecosystem services in agroecosystems.

Birds are considered good indicators of habitat quality, showing sensitivity and rapid responses to anthropogenic changes in the environment because of their mobility and position in the upper trophic levels of agroecosystems (Heldbjerg, Sunde, \& Fox, 2018). Moreover, birds are one of the most diverse groups of ecosystem-service providers (Sekercioglu, 2006). Thus, functional patterns of bird assemblages may represent a good approximation to understand the productive and environmental benefits related to agroecological management.

Several studies have promoted the conservation of birds in rice fields because these agroecosystems may support a high abundance and diversity of birds (Acosta et al., 2010; Stafford et al., 2010). Here, we compared functional diversity of birds found in rice fields under conventional and agroecological management in the rice zone of Santa Fe Province, Argentina. Because agrochemicals reduce the herbaceous and shrubby spontaneous plants cover, as well as the abundance of trophic resources such as the supply of invertebrates, we expect a greater functional diversity and different functional composition in the agroecological rice field related to these environmental differences.

\section{MATERIALS AND METHODS}

Study Area: The study area included the rice zone located in the Eastern part of Santa Fe Province, Mid-Eastern Argentina. This zone covers a North-South band, approximately $10-20 \mathrm{~km}$ wide, West of the San Javier River, which is part of the Parana River system, from approximately Romang (2929' S \& 59 45' W) in the North to Cayasta $\left(31^{\circ} 11^{\prime} \mathrm{S} \& 60^{\circ} 9^{\prime}\right.$ ' $\mathrm{W})$ in the South. This area is characterized by xerophilous forests of the Espinal ecoregion at higher elevations, and by marshes and flooded grasslands in lower elevations (López-Lanús \& Marino, 2010), mixed with some floristic elements of Delta and Islands of Parana River ecoregion (Burkart, 1999).

Rice fields under two different management practices were selected: conventional rice fields, with the use of pesticides in the production process, and agroecological rice fields, with no application of chemical or biological pesticides. In general, conventional management includes application by airplane of different agrochemicals: -herbicides such as glyphosate before sowing for the control of grasses; -fungicides such as bentazone and clomazone; and - insecticides such as organophosphate (chlorpyrifos) and pyrethroids (lambda-cyhalothrin) for the control of arthropods at flowering (Romero, Potter, \& Haynes, 2009; Attademo et al., 2015). Fertilizers are also applied when plants are 7-10 days old (Attademo, Lorenzón, Peltzer, \& Lajmanovich, 2018). Agroecological rice fields presented several spontaneous plants (e.g., Ludwigia sp., Sagittaria montevidensis, Aeschynomene sp., Pistia stratiotes, Polygonum sp.) intermixed 
with rice plants. Conventional and agroecological rice fields were separated by a distance of $14 \mathrm{~km}$.

Bird Sampling: Birds sampling was carried out in four sites by type of rice field (i.e., conventional and agroecological). Sampling was repeated eight times every 15 days between November 2017 and March 2018, which encompassed the rice season from beginning of sowing until a few days before harvest. Thus, effect of phenology of rice on bird detectability (e.g. detectability of species that feed on the ground may be less when the rice increases its height) did not affect the comparison between rice fields because this was synchronous and it was present similarly under the two types of rice managements. An additional survey was performed after the harvest to sample the assemblages of birds once rice cultivation and management techniques were not present. In each site and during each of the nine surveys, birds were sampled by a combined technique of line transects and point counts that were repeated during the morning and the afternoon (i.e., from dawn until four hours after sunrise and again starting four hours before sunset, respectively). A 140-m long line transect was established in each site along the edges of each rice field. Walking surveys (14-min duration) were conducted along transects during days without wind or rain. All birds seen and heard from the field edge up to $100-\mathrm{m}$ within the field (i.e., only counting birds on the crop side of transect; Freemark \& Rogers, 1995) were counted. In addition to the transect, a 10-min point count was established at the beginning and end of each transect; point-counts covered a rectangular area that included only an angle of 90 degrees from each point because points were located at the corners of the rice-field plots (Digital Appendix 1). Thus, all birds in a $70 \mathrm{~m}$ (i.e. up to the half of transect) $\times 100 \mathrm{~m}$ area within the rice fields and at the edges (range-finders were used for distance determinations) were recorded. Thus, transects and point counts (both points combined) sampled the same area and the higher abundances by species of the two methods was used for data analysis. A relatively large detection distance $(100 \mathrm{~m})$ was used because of the good visibility within rice fields. Although by this detection distance a subsampling of some species (e.g., species that feed on the ground when rice is relatively high) could occur, this subsampling did not affect the comparison between types of rice fields because it was present in the two types of rice fields and it allowed to record many other species such as passerines that use rice fields in the stages in which the rice plant is relatively high. To avoid area and spatial-autocorrelation effects, an equal area was sampled in each rice field locating transects and points at the same distance in each one (Chiarucci, Bacaro, Rocchini, Ricotta, \& Palmer, 2009). The four transects by type of management were sampled in two pairs, with transects within each pair located $\approx 150 \mathrm{~m}$ apart. The two contiguous transects within each pair were sampled by two observers simultaneously to improve independence (Giraudo, Matteucci, Alonso, Herrera, \& Abramson, 2008). Pairs of transects were separated by at least 250 meters. We considered that this distances together with the simultaneous sampling were sufficient to avoid obtaining records of individuals that could come from nearby transects. Several bird studies use similar distances (e.g. Leveau, 2013; Cristaldi, Giraudo, Arzamendia, Bellini, \& Claus, 2017). Conventional and agroecological rice fields were sampled during two consecutive days to ensure that the fields were sampled at the same time of day.

Functional traits: Functional analyses were based on traits related with habitat requirements and a bird's ability to exploit resources (i.e. their trophic niche). These traits were body size (continuous trait, $\mathrm{cm}$ ), habitat (categorical trait with three categories -terrestrial, wetlands and aquatic), diet (categorical trait reflecting the predominant items in the diet -omnivore, carnivore, herbivore and insectivore), components of diet (binary traits for each of eight categories of prey -fruits, stems and leaves, seeds, nectar, invertebrates, 
fishes, other vertebrates, carrion), foraging substrate (binary traits for each of eight categories -water, ground, mud, stratum herbaceous, shrub and arboreal, bark and air), and foraging method or strategy (binary traits for each of eight categories -gleaning, probing, pursuit, hunting from the air, pouncing, digging, filtration, and scavenging; Digital Appendix 2 ). These traits were selected because they can drive biodiversity and ecosystem function relationships, and they are generally used to evaluate effects of environmental changes on the functional diversity of birds (Sekercioglu, 2006; Flynn et al., 2009; Philpott et al., 2009; Mönkkönen, Devictor, Forsman, Lehikoinen, \& Elo, 2017). Assignment of species' traits was based on information available in the literature of the region (Digital Appendix 3).

Functional diversity and composition: We calculated four indices of functional diversity: functional richness, divergence, evenness and dispersion. These indices quantify different and complementary facets of functional diversity for an assemblage, with species distributed in a multidimensional functional space (Villéger et al., 2008). Functional richness (FRic) represents the volume of the functional space occupied by the assemblage and it is defined as the amount of niche space occupied by the species within an assemblage. Functional divergence (FDiv) measures the divergence in the distribution of abundance in this volume indicating how abundance is distributed within the volume of functional trait space occupied by species. Functional evenness (FEve) represents the regularity of the distribution of abundance in this volume measuring both the regularity of spacing between species along a functional trait gradient and evenness in the distribution of abundance across species (Villéger et al., 2008). Functional dispersion (FDis), proposed later by Laliberté \& Legendre (2010), represents the mean distance of individual species to the centroid of all species in the assemblage, considering relative abundances of species. Multidimensional functional space was calculated by a Principal
Coordinates Analysis (PCoA) performed on a trait-based Gower dissimilarity matrix of the bird species. Because distance matrix was not Euclidean, correction by square-root transformation was applied. We assigned proportional values to categorical traits by calculating the weight: $W i=1 / N i$, where $N i$ is the number of characters by which the categorical trait $i$ was divided (Laliberté \& Legendre, 2010). Resulting PCoA axes were used as the new 'traits' to compute FRic, FDiv and FEve. The first two axes of the PCoA were used to calculate FRic and FDiv because both indices require more species than traits; for FEve, because there is no limit on the number of traits that can be used, all PCoA axes were used (Villéger et al., 2008; Laliberté \& Legendre, 2010; Laliberté, Legendre, \& Shipley, 2014). For these three indices, a functional diversity measure of zero was assigned to samples containing two or fewer species because computing the functional space was not possible. FDis was computed from the uncorrected species-species distance matrix; a FDis value of 0 was assigned to samples composed of only one species (Laliberté \& Legendre, 2010). Community-level weighted means of trait values (CWM) were used to represent functional composition by sample (Lavorel et al., 2008). For continuous traits (e.g. body size), CWM is the mean trait value of all species present in the community weighted by their relative abundances. For categorical traits (e.g., habitat, trophic guild), the abundance of each individual class of the trait was considered (Laliberté \& Legendre, 2010). All functional indices were calculated using the 'dbFD' function of package FD (Laliberté et al., 2014) in R (R Core Team, 2017).

Data analysis: Samples obtained during the cultivation stages (from sowing until a few days before harvest, $\mathrm{N}=$ four transects $\mathrm{x}$ two times/day $\mathrm{x}$ eight surveys $\mathrm{x}$ two management types $=128$ total samples; 9 samples were interrupted by rain and were not included) were considered together while the post-harvest samples $(\mathrm{N}=$ four transects $\mathrm{x}$ two times/day $\mathrm{x}$ one survey $\mathrm{x}$ two management 
types $=16$ samples) were considered separately for statistical comparisons between management types. Post-harvest comparison of the fields was performed because this comparison can provide additional information about the differences between managements. For example, a higher functional diversity under conventional management, or not differences between managements, during post-harvest comparison against a higher functional diversity under agroecological management during stages of the cultivation could indicate that differences between managements are related to the active agroecological practices (e.g., weed management). On the other hand, a lower functional diversity under conventional management even during post-harvest comparison could indicate the influence of the residual presence of pesticides and/or, more important, the influence of pre-existing differences (e.g., landscape context) between fields on the results. Comparison of functional indices between rice-field management types was performed through general mixed models (LMM) with transect identity as random intercepts $(\mathrm{N}=8)$ to account for repeated samples (i.e., repeated surveys in each transect every 15 days and in two times of day -morning and afternoon- are not statistically independent). Fixed factor in all models included the type of management (categorical variable with two levels, conventional and agroecological). Additionally, to assess whether species richness could be used as a surrogated of functional indices because differences of functional indices between types of managements reflect differences in species richness, models including species richness as a covariate were performed in cases in which functional indices varied between management types and a correlation between functional indices and species richness (Pearson correlation, $\mathrm{P}<0.1$ ) was found. Residual plots (quantilequantile plots and residuals vs. fitted values) were used to assess model fit and absence of autocorrelation. Significance $(P<0.05)$ of the fixed factor (type of management) was assessed by permutation-based likelihood-ratio tests (999 permutations) for nested models (i.e., by comparison of the mixed models with and without the presence of this factor). These analyses were performed using the packages lme4 (Bates, Mächler, Bolker, \& Walker, 2015) and predictmeans (Luo, Ganesh, Koolaard, \& Luo, 2018) for LMMs in R (R Core Team, 2017).

A constrained distance-based redundancy analysis (dbRDA) was used to compare community-level weighted means of trait values (CWM) by sample between conventional and agroecological managements. The dbRDA was performed using the 'capscale' function in the vegan package (Oksanen et al., 2015) for $\mathrm{R}(\mathrm{R}$ Core Team, 2017). The Bray-Curtis-based trait dissimilarity matrix was relativized through Wisconsin double standardization where traits are first standardized by maxima and then sites by site totals (Oksanen, 2011). Significance of the constrained fraction for management type was evaluated by a permutation test (999 permutations).

\section{RESULTS}

General results: We recorded a total of 10524 detections representing 107 species (Digital Appendix 2). During the pre-harvest period we recorded a mean \pm SE per survey of $598.7 \pm 254.5$ detections and $17.5 \pm 1.2$ species under conventional management and of 627.1 \pm 132.3 and $31 \pm 2.3$ species under agroecological management. During the post-harvest period were recorded 120 detections and 14 species under conventional management and 1394 detections and 28 species under agroecological management. The most abundant species under conventional management were Chrysomus ruficapillus (3 509 detections), Calidris melanotos (194 detections) and Dolichonyx oryzivorus (133 detections), while the most abundant species under agroecological management were C. ruficapillus (1 759 detections), C. melanotos (369 detections) and Jacana jacana (260 detections).

Comparison of functional diversity between conventional and agroecological rice-fields: During the period that covered the cultivation of rice, functional richness, 
divergence and dispersion were higher under agroecological management. Moreover, except functional divergence, these functional indices were correlated with species richness (Table 1). Once this correlation was accounted for in the analysis, only functional dispersion, in addition to functional divergence that was not associated with species richness, still showed a significantly higher value under agroecological management (Table 1). After the rice was harvested, functional evenness was higher on the field that had experienced conventional management but no other indices differed between fields (Table 1).

Comparison of functional composition between conventional and agroecological rice-fields: Community-level weighted means of trait values by sample differed between conventional and agroecological managements (dbRDA: $\mathrm{R}^{2}=0.15, F_{1,117}=18.2, \mathrm{P}=0.001$, Fig. 1). Species that were associated with wetland habitats, that were omnivorous or had a seed-based diet, that used gleaning as foraging method, and foraged on the ground or in mud were more important in the field under conventional management. In contrast, species associated with terrestrial habitats, were insectivorous, used pursuit as a foraging method, and that foraged in the air and in shrubs were best represented in the field under agroecological management (Fig. 1).

\section{DISCUSSION}

Several studies have shown that agroecological and organic methods enhance biodiversity in rice farms (e.g. Wickramasinghe, Harris, Jones, \& Vaughan, 2003; Mesléard, Garnero, Beck, \& Rosecchi, 2005; Ibáñez, Curcó, Riera, Ripoll, \& Sánchez, 2010). However, these comparisons have been based on taxonomic indices such as species richness, diversity and abundance of species. Thus, not enough studies are available on functional diversity. Studies on functional diversity are important because ecosystem-level processes are affected by the functional characteristics of organisms

\section{TABLE 1}

Functional diversity between conventional and agroecological rice-fields

\begin{tabular}{|c|c|c|c|c|c|c|c|c|}
\hline & \multicolumn{2}{|c|}{ Mean \pm SE } & \multicolumn{2}{|c|}{$\begin{array}{c}\text { Comparison } \\
\text { between } \\
\text { managements }\end{array}$} & \multicolumn{2}{|c|}{$\begin{array}{l}\text { Correlation } \\
\text { with species } \\
\text { richness }\end{array}$} & \multicolumn{2}{|c|}{$\begin{array}{c}\text { Comparison } \\
\text { accounting for } \\
\text { species richness }\end{array}$} \\
\hline & Conv & Agroec & LRT & $\mathrm{P}$ & $\mathrm{r}$ & $\mathrm{P}$ & LRT & $\mathrm{P}$ \\
\hline \multicolumn{9}{|l|}{ Sampling during cultivation } \\
\hline Functional richness & $0.11 \pm 0.01$ & $0.17 \pm 0.01$ & 16.27 & 0.001 & 0.66 & $<0.001$ & 0.004 & 0.953 \\
\hline Functional divergence & $\mathbf{0 . 5 5} \pm \mathbf{0 . 0 3}$ & $0.66 \pm 0.03$ & 4.80 & 0.045 & 0.06 & 0.532 & - & - \\
\hline Functional evenness & $0.51 \pm 0.03$ & $0.61 \pm 0.01$ & 4.32 & 0.084 & 0.22 & 0.016 & - & - \\
\hline Functional dispersion & $0.12 \pm 0.01$ & $0.21 \pm 0.01$ & 17.12 & 0.001 & 0.46 & $<0.001$ & 13.80 & 0.002 \\
\hline \multicolumn{9}{|l|}{ Sampling after harvest } \\
\hline Functional richness & $0.09 \pm 0.02$ & $0.12 \pm 0.03$ & 0.74 & 0.411 & 0.73 & 0.001 & - & - \\
\hline Functional divergence & $0.70 \pm 0.11$ & $0.81 \pm 0.12$ & 0.50 & 0.492 & 0.58 & 0.018 & - & - \\
\hline Functional evenness & $0.69 \pm 0.10$ & $0.42 \pm 0.08$ & 4.03 & 0.048 & 0.04 & 0.883 & - & - \\
\hline Functional dispersion & $0.17 \pm 0.02$ & $0.12 \pm 0.02$ & 3.15 & 0.094 & -0.25 & 0.355 & - & - \\
\hline
\end{tabular}

Mean \pm SE, statistical comparison (LRT, likelihood ratio test), correlation with species richness (r, coefficient of correlation of Pearson) and comparison controlled by species richness of functional indices between conventional (Conv) and agroecological (Agroec) management of rice fields during the cultivation $(\mathrm{N}=$ four transects $\mathrm{x}$ two times/day $\mathrm{x}$ eight surveys $\mathrm{x}$ two management types $=128$ total samples $)$ and post-harvest $(\mathrm{N}=$ four transects $\mathrm{x}$ two times/day $\mathrm{x}$ one survey $\mathrm{x}$ two management types $=16$ samples) periods. Controlled by species richness analysis was performed only when functional indices differed between management practices and a correlation between functional indices and species richness was found. Bold values indicate significant variation or correlation. 


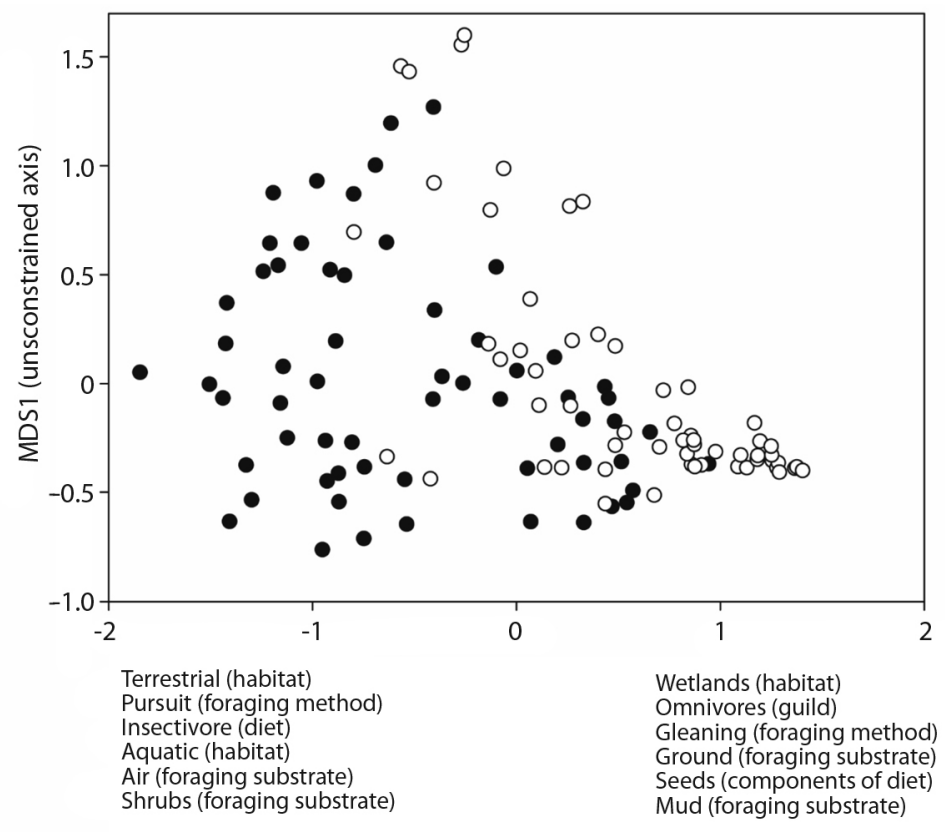

CAP1 (constrained axis)

Fig. 1. Constrained distance-based redundancy ordination (dbRDA) relating community-level weighted means of trait values by sample to type of management (conventional and agroecological, represented by open and filled circles, respectively) of rice fields. Each circle represents the community-level weighted means of trait values (CWM) by sample $(\mathrm{N}=$ four transects $\mathrm{x}$ two times/day $\mathrm{x}$ eight surveys $\mathrm{x}$ two management types $=128$ total samples, see data analysis subsection). Traits most strongly associated with the constrained axis (CAP1) are indicated.

involved rather than by taxonomic identity (Hooper et al., 2002). Here, studying birds in rice fields under different types of management, a higher functional richness, divergence and dispersion was found in agroecological than in conventional rice fields. Only the higher functional bird richness in agroecological rice field was accounted for by differences in species richness. Instead, functional bird divergence was not associated with bird species richness and functional bird dispersion still differed between management types even after the effect of species richness was accounted for in the analysis, indicating that the influence of management practices on bird functional diversity found cannot be inferred completely from species richness. Similarly, previous studies have indicated that taxonomic-based biodiversity patterns cannot be used as surrogates of ecosystem function (Mayfield et al., 2010;
Cadotte et al., 2011). On the other hand, functional diversity did not differ between the two rice fields after the rice was harvested and the management practices were no longer present (contrary, a higher functional evenness was found under conventional management). Thus, our results suggest that differences between the rice fields were related to the active agroecological practices (e.g., weed management) and that the difference found between rice field managements was not related to preexisting differences (e.g., landscape context) between fields.

Bird functional indices here considered provide complementary information on the structure of assemblages. Higher functional richness in agroecological field suggests that birds under this type of management perform a higher number of roles in the ecosystem. Moreover, the positive association between 
functional richness and species richness found indicates that different species perform different roles in the agroecosystem, because this association is present when species' traits are equally complementary (Petchey \& Gaston, 2002). The remaining indices consider the abundance of the species. Functional divergence point out that dominant bird species are ecologically more diverse (i.e., greater niche differentiation; Mason, Mouillot, Lee, \& Wilson, 2005) under agroecological management. This finding highlights an important benefit of agroecological management because it suggests an increase in the magnitude of bird ecosystem functions due to a more efficient resource use under this management. Lastly, functional dispersion is a complementary index to functional richness because it is not sensitive to outliers (i.e. rare species with extreme trait values do not inflate functional dispersion) and because it considers abundances of species (Laliberté \& Legendre, 2010). A higher functional dispersion indicates a wider dispersion of species in the functional space because of increases in abundance or appearance of species with more extreme trait values (Laliberté \& Legendre, 2010; Arruda Almeida, Green, Sebastian-Gonzalez, \& dos Anjos, 2018). Assemblages with higher functional dispersion values sustain a wider range of ecological traits, suggesting a wider range of bird-mediated ecological functions (Arruda Almeida et al., 2018).

Composition of bird traits also varied between conventional and agroecological rice fields, suggesting differences in habitat conditions existed between fields. The insectivore diet was best represented in the agroecological field, probably due to a higher abundance of insects. Previous studies have found a greater abundance of insects in crops managed without application of agrochemicals (e.g. Moreby, Aebischer, Southway, \& Sotherton, 1994; Krauss, Gallenberger, \& Steffan-Dewenter, 2011) as a result of both the lack of insecticides use (Mesléard et al., 2005; Sekercioglu, 2012) and of the greater abundance of spontaneous plants due to the lack of herbicides use (Moreby et al., 1994). Other traits such as pursuit foraging and aerial foraging also reflected the higher abundance of insectivorous birds under agroecological management because these are associated with species that pursue insects in flight in the air (e.g., Hirundinidae) or by short flights from perches (e.g. Tyrannidae). In addition, many insectivores mostly foraged in shrubs (e.g., Furnariidae, Tyrannidae), a substrate that was also visibly better represented under agroecological management during bird samplings. This higher cover of shrubs substrate was associated to growth of shrub on the edges of the agroecological rice field because of non-application of herbicides. Thus, these results highlight that agroecological management may be productively successful for agriculture because insectivorous birds can remove and control herbivorous arthropods (Johnson, Kellermann, \& Stercho, 2010; Sekercioglu, 2012). Moreover, use of herbicides in the field under conventional management may help account for the greater abundance of birds that forage on the ground and on mud substrates because of the lower cover of spontaneous plants. Many of these ground-foraging species consume seeds (e.g. Icteridae, Columbidae), which could explain the better representation of birds with a seed-based diet in the field under conventional management.

One of the guiding principles of agroecology is an increase in ecosystem services provided by enhanced biodiversity (Altieri, 1999). Accordingly, our study contributes to this goal with preliminary evidence that agroecological management of rice crops increases bird functional diversity and the representativeness of important bird functional traits for crop management, such as the insectivore diet, a key trait for the biological control of herbivorous arthropods. Thus, these results suggest that provision of ecosystem services, which is strongly modulated by functional diversity (Liere et al., 2017), is enhanced through this type of management. In addition, the greater functional diversity of birds found in the agroecological field indicates that this type of management supports rice fields with greater variability in ecological niches that can be occupied by 
more diverse assemblages of birds, an aspect that makes the agroecological rice fields more compatible with the conservation of birds in these agroecosystems.

Ethical statement: authors declare that they all agree with this publication and made significant contributions; that there is no conflict of interest of any kind; and that we followed all pertinent ethical and legal procedures and requirements. All financial sources are fully and clearly stated in the acknowledgements section. A signed document has been filed in the journal archives.

\section{ACKNOWLEDGMENTS}

We are grateful to farmers (Cooperativa "El Progreso" and Cooperativa "Villa Elisa") for permission to fieldwork in their farms and to Secretaria de Agricultura Familiar de la Nación Argentina by assistance during the fieldwork. We are grateful to John G. Blake for English editing and constructive comments on the drafts of this paper. This work was carried out under the project "Importancia de los bordes de campo de arroz orgánico en el rol de los vertebrados en el control biológico de plagas" supported by Curso de Acción para la Investigación y Desarrollo (Programa de I+D Orientado a Problemas Sociales y Productivos, UNL) whose directors are A. M. Attademo and P. M. Peltzer.

\section{RESUMEN}

¿Puede el manejo agroecológico incrementar la diversidad funcional de aves en campos de arroz? Introducción: El reconocimiento de la variedad de servicios ecosistémicos de la biodiversidad en los agroecosistemas es uno de los principios básicos de la agroecología. Debido a que los índices de diversidad funcional pueden estar directamente relacionados con los servicios ecosistémicos, la evaluación de la diversidad funcional representa una estrategia adecuada para evaluar estos servicios en agroecosistemas bajo manejo agroecológico. Objetivo: $\mathrm{Se}$ comparó la diversidad funcional de aves entre arroceras bajo manejo convencional y agroecológico en la zona arrocera de la provincia de Santa Fe, Argentina. El objetivo fue determinar si el manejo agroecológico del arroz se asocia con una mayor diversidad funcional y con una diferente composición funcional de aves en relación con el manejo convencional. Métodos: Se muestrearon las aves mediante 8 conteos repetidos aproximadamente cada 15 días entre noviembre 2017 y marzo 2018, desde el comienzo de la siembra hasta antes de la cosecha, en ambos tipos de arroceras. Los muestreos fueron realizados mediante una técnica mixta combinando transectas de línea y puntos de conteo en cuatro sitios por tipo de manejo. Se calcularon índices de diversidad y composición funcional con base en atributos morfológicos y tróficos de las aves registradas. Resultados: La riqueza, la divergencia y la dispersión funcional fueron más altos bajo manejo agroecológico. Solamente en el caso de la riqueza funcional las diferencias reflejaron únicamente la variación de la riqueza de especies. La media ponderada a nivel de ensamble de los valores de los rasgos por muestra varió entre los tipos de manejo, estando la dieta insectívora, la persecución como método de forrajeo, y el aire y los arbustos como sustrato de forrajeo mejor representados bajo manejo agroecológico. Conclusión: Los resultados sugirieron que el manejo agroecológico del arroz se relaciona con una mayor diversidad funcional de aves que las prácticas de manejo convencional, sugiriendo que el manejo agroecológico puede mejorar la provisión de servicios ecosistémicos por aves en cultivos de arroz.

Palabras clave: agroecosistema; Argentina; manejo convencional; servicio ecosistémico; Provincia de Santa Fe; rasgo funcional.

\section{REFERENCES}

Acosta, M., Mugica, L., Blanco, D., López-Lanús, B., Dias, R.A., Doodnath, L.W., \& Hurtado, J. (2010). Birds of rice fields in the Americas. Waterbirds, 33, 105-122.

Altieri, M.A. (1999). The ecological role of biodiversity in agroecosystems. Agriculture, Ecosystems \& Environment, 74, 19-31.

Arruda Almeida, B., Green, A.J., Sebastian-Gonzalez, E., \& dos Anjos, L. (2018). Comparing species richness, functional diversity and functional composition of waterbird communities along environmental gradients in the neotropics. PloS one, 13.

Attademo, A., Lorenzón, R., Peltzer, P., \& Lajmanovich, R. (2018). Diversity of Anurans in Rice Fields under Organic and Conventional Management in Santa Fe Province, Argentina. Herpetological Review, 49, 632-635.

Attademo, A.M., Peltzer, P.M., Lajmanovich, R.C., Cabagna-Zenklusen, M., Junges, C.M., Lorenzatti, E., ... Grenón, P. (2015). Biochemical changes in certain enzymes of Lysapsus limellium (Anura: Hylidae) exposed to chlorpyrifos. Ecotoxicology \& Environmental Safety, 113, 287-294. 
Bates, D., Mächler, M., Bolker, B., \& Walker, S. (2015). Fitting Linear Mixed-Effects Models using lme4. Journal of Statistical Software, 67. DOI: 10.18637/ jss.v067.i01

Burkart, R., Bárbaro, N.O., Sánchez, R.O., \& Gómez, D.A. (1999). Ecorregiones de la Argentina. Buenos Aires, Argentina: Administración de Parques Nacionales y Secretaría de Recursos Naturales y Desarrollo Sustentable.

Cadotte, M.W., Carscadden, K., \& Mirotchnick, N. (2011). Beyond species: functional diversity and the maintenance of ecological processes and services. Journal of Applied Ecology, 48, 1079-1087.

Chiarucci, A., Bacaro, G., Rocchini, D., Ricotta, C., \& Palmer, M.W. (2009). Spatially constrained rarefaction: incorporating the autocorrelated structure of biological communities into sample-based rarefaction. Community Ecology, 10, 209-214.

Cristaldi, M.A., Giraudo, A.R., Arzamendia, V., Bellini, G.P., \& Claus, J. (2017). Urbanization impacts on the trophic guild composition of bird communities. Journal of Natural History, 51, 2385-2404.

Flynn, D.F.B., Gogol-Prokurat, M., Nogeire, T., Molinari, N., Richers, B.T., Lin, B.B., ... DeClerck, F. (2009). Loss of functional diversity under land use intensification across multiple taxa. Ecology Letters, 12, 22-33. DOI: 10.1111/j.1461-0248.2008.01255.x

Freemark, K., \& Rogers, C. (1995). Modification of point counts for surveying cropland birds. (1995). In C.J. Ralph, J.R. Sauer, \& S. Droege (Eds.), Monitoring Bird. Populations by Point Counts (pp. 69-74). Albany, USA: U.S. Department of Agriculture, Forest Service, Pacific Southwest Research Station.

Giraudo, A.R., Matteucci, S.D., Alonso, J., Herrera, J., \& Abramson, R.R. (2008). Comparing bird assemblages in large and small fragments of the Atlantic Forest hotspots. Biodiversity \& Conservation, $17,1251-1265$.

Heldbjerg, H., Sunde, P., \& Fox, A.D. (2018). Continuous population declines for specialist farmland birds 1987-2014 in Denmark indicates no halt in biodiversity loss in agricultural habitats. Bird Conservation International, 28, 278-292.

Hooper, D.U., Chapin, F.S., Ewel, J.J., Hector, A., Inchausti, P., Lavorel, S., ... Naeem, S. (2005). Effects of biodiversity on ecosystem functioning: a consensus of current knowledge. Ecological Monographs, $75,3-35$.

Hooper, D.U., Solan, M., Symstad, A., DõÂaz, S., Gessner, M.O., Buchmann, N., ... van Peer, L. (2002). Species diversity, functional diversity, and ecosystem functioning. In M. Loreau, S. Naeem, \& P. Inchausti (Eds.), Biodiversity and Ecosystem Functioning, Synthesis and Perspectives (pp. 195-208). Oxford, UK: Oxford University Press.

Ibáñez, C., Curcó, A., Riera, X., Ripoll, I., \& Sánchez, C. (2010). Influence on birds of rice field management practices during the growing season: a review and an experiment. Waterbirds, 33, 167-180.

Johnson, M.D., Kellermann, J.L., \& Stercho, A.M. (2010). Pest reduction services by birds in shade and sun coffee in Jamaica. Animal Conservation, 13, 140-147.

Krauss, J., Gallenberger, I., \& Steffan-Dewenter, I. (2011). Decreased Functional Diversity and Biological Pest Control in Conventional Compared to Organic Crop Fields. PLoS ONE, 6, e19502. DOI:10.1371/journal. pone.0019502

Laliberté, E., \& Legendre, P. (2010). A distance-based framework for measuring functional diversity from multiple traits. Ecology, 91, 299-305.

Laliberté, E., Legendre, P., \& Shipley, B. (2014). FD: measuring functional diversity from multiple traits, and other tools for functional ecology. R package version $1.0-12$

Lavorel, S., Grigulis, K., McIntyre, S., Williams, N.S., Garden, D., Dorrough, J., ... Bonis, A. (2008). Assessing functional diversity in the field-methodology matters! Functional Ecology, 22, 134-147.

Letourneau, D.K., \& Bothwell, S.G. (2008). Comparison of organic and conventional farms: challenging ecologists to make biodiversity functional. Frontiers in Ecology and the Environment, 6, 430-438. DOI:10.1890/070081

Leveau, L.M. (2013). Bird traits in urban-rural gradients: how many functional groups are there? Journal of Ornithology, 154(3), 655-662.

Liere, H., Jha, S., \& Philpott, S.M. (2017). Intersection between biodiversity conservation, agroecology, and ecosystem services. Agroecology and Sustainable Food Systems, 41, 723-760.

López-Lanús, B., \& Marino, G.D. (2010). Aportes al conocimiento de la Ecología del Charlatán y su estado actual en la Provincia de Santa Fe, Argentina, Temas de Naturaleza \& Conservación/Monografía de Aves Argentinas № 7. Buenos Aires, Argentina: Aves Argentinas / Asociación Ornitológica del Plata.

Luo, D., Ganesh, S., Koolaard, J., \& Luo, M.D. (2018). Package 'predictmeans'. Retrieved from https:// cran.r-project.org/web/packages/predictmeans/ index.html

Mason, N.W., Mouillot, D., Lee, W.G., \& Wilson, J.B. (2005). Functional richness, functional evenness and functional divergence: the primary components of functional diversity. Oikos, 111, 112-118. 
Mayfield, M.M., Bonser, S.P., Morgan, J.W., Aubin, I., McNamara, S., \& Vesk, P.A. (2010). What does species richness tell us about functional trait diversity? Predictions and evidence for responses of species and functional trait diversity to land-use change. Global Ecology \& Biogeography, 19, 423-431. DOI:10.1111/j.1466-8238.2010.00532.x

Mesléard, F., Garnero, S., Beck, N., \& Rosecchi, É. (2005). Uselessness and indirect negative effects of an insecticide on rice field invertebrates. Comptes Rendus Biologies, 328, 955-962.

Mönkkönen, M., Devictor, V., Forsman, J.T., Lehikoinen, A., \& Elo, M. (2017). Linking species interactions with phylogenetic and functional distance in European bird assemblages at broad spatial scales. Global Ecology \& Biogeography, 26, 952-962.

Moreby, S.J., Aebischer, N.J., Southway, S.E., \& Sotherton, N.W. (1994). A comparison of the flora and arthropod fauna of organically and conventionally grown winter wheat in southern England. Annals of Applied Biology, 125, 13-27.

Oksanen, J. (2011). Multivariate Analysis of Ecological Communities in R: vegan tutorial. Retrieved from www.cran.r-project.org

Oksanen, J., Blanchet, F.G., Kindt, R., Legendre, P., Minchin, P.R., O’Hara, R.B., ... Wagner, H. (2015). vegan: Community Ecology Package. $\mathrm{R}$ package version 2.3-0.

Petchey, O.L., \& Gaston, K.J. (2002). Functional diversity (FD), species richness and community composition. Ecology Letters, 5, 402-411.

Philpott, S.M., Soong, O., Lowenstein, J.H., Pulido, A.L., Lopez, D.T., Flynn, D.F., \& DeClerck, F. (2009). Functional richness and ecosystem services: bird predation on arthropods in tropical agroecosystems. Ecological Applications, 19, 1858-1867.

R Core Team (2017). R: A language and environment for statistical computing. Version 3.4.2. R Foundation for Statistical Computing. Vienna, Austria.

Romero, A., Potter, M.F., \& Haynes, K.F. (2009). Evaluation of piperonyl butoxide as a deltamethrin synergist for pyrethroid-resistant bed bugs. Journal of Economic Entomology, 102, 2310-2315.

Sans, F.X. (2007). La diversidad de los agroecosistemas. Revista Ecosistemas, 16, 44-49.

Sekercioglu, C.H. (2012). Bird functional diversity and ecosystem services in tropical forests, agroforests and agricultural areas. Journal of Ornithology, $153,153-161$.

Sekercioglu, C.H. (2006). Increasing awareness of avian ecological function. Trends in Ecology \& Evolution, $21,464-471$.

Stafford, J.D., Kaminski, R.M., \& Reinecke, K.J. (2010). Avian foods, foraging and habitat conservation in world rice fields. Waterbirds, 33, 133-150.

Villéger, S., Mason, N.W., \& Mouillot, D. (2008). New multidimensional functional diversity indices for a multifaceted framework in functional ecology. Ecology, 89, 2290-2301.

Wezel, A., \& Soldat, V. (2009). A quantitative and qualitative historical analysis of the scientific discipline of agroecology. International Journal of Agriculture Sustainable, 7, 3-18.

Wickramasinghe, L.P., Harris, S., Jones, G., \& Vaughan, N. (2003). Bat activity and species richness on organic and conventional farms: impact of agricultural intensification. Journal of Applied Ecology, 40, 984-993. 